\title{
Task-based Language Teaching and Text Types in Teaching Writing Using Communicative Approach
}

\author{
Ni Nyoman Riyana Sari*, Dewa Komang Tantra , and Made Hery Santosa \\ Universitas Pendidikan Ganesha Bali Indonesia
}

\begin{abstract}
One of the most important language competencies in teaching learning process is writing. The present study focused on investigating the effect of communicative approach with task-based language teaching and communicative approach on the students' writing competency at SMP N 2 Kediri viewed from text types(i.e. descriptive, recount, and narrative). To analyze the data, the design of the experimental study was posttest-only comparison groups by involving 60 students that were selected as the sample of the study through cluster random design. The sample's post tests were assessed by using analytical scoring rubric. The data were then analyzed by using One-way ANOVA and the post hoc test was done by computing Multiple Comparison using Tukey HSD Test. The result showed that there was significant difference of the effect of communicative approach with task-based language teaching and communicative approach on the students' writing competency. These findings are expected to give contribution in teaching English, particularly writing.
\end{abstract}

Keywords: Tasks-based language teaching, text types, writing competency, and communicative approach

\section{Introduction}

According to Coffin, Curry, Goodman, Hewings, Lillis and Swan (2003), the main point of teaching and learning process in higher educational level is writing. Moreover, writing is also the centre of a range of purposes fulfillment based on the various contexts where writing should be done. The purposes of writing as a higher educational context changer can be divided into three, assessment, learning and entering particular disciplinary communities.

The previous statement is also supported by Hyland (2003, p. xv). He states that writing's position is very fundamental among the other skills such as listening, speaking and reading. The development of writing skill must be further increased because the skill of teaching writing will show how skillful is the English teacher. Teaching writing is not a piece of cake. The teacher must be able to elaborate the teaching style with the teaching 
material. When the teacher has a good capability in writing, it can be assumed that the teacher should be able to become a good model for the language learners.

Besides the above theories, the important of writing also can be seen from the researcher that did a study about writing. Marashi and Dadari (2012) say that nowadays, writing has shown its importance especially in daily lives. It can be seen from a side, specifically where written form has been becoming a dominant language among the world's population and speakers. Moreover, Tilfarliogu and Basaran, (2007) advised that writing is categorized as the trend centre of research topic especially in the relation of second language learning. In addition, they also said that writing has a role in language learning as a tool in the teaching learning process. Therefore, it can be synthesized that writing is one of the most important competency that should be mastered by the students as every single thing in teaching is related to writing.

From the above explanation, we can see how important writing is for the students. Those make the researcher eager to conduct a study about writing and implement a writing strategy for the students under the study. In order to know how the implementation of teaching writing in SMP N 2 Kediri, the researcher did a preliminary observation towards the teaching learning process of English subject, especially writing. In addition, an interview with the English teacher and the students was also done by the researcher to get further information about the teaching learning process.

After doing observation and interview, the researcher found that most of the eighth grade students of SMP N 2 Kediri are still unable to write a good text in English. According to the English teacher, most of the students could not pass the standard minimum score criteria in writing which is 74.00 . The students are still not able to develop their idea properly in writing text. As a result, they are not able to write a good text. They were given a chance to write a text in English, but they did not know what to write because the teacher only asked them to write a text that has similar type with the one teacher had. There is no further instruction what should be there in the text. At this stage, we can see that the task given by the teacher is not clear so the students couldn't know how is the correct process of writing. Where they should be able to produce a good writing product especially writing there were three kinds of texts to be mastered by the eighth grade students, they are descriptive, recount and narrative text.

At this stage, something must be done to solve the students' problem in learning writing. As what have been mentioned previously that the tasks given by the teacher is not clear, the researcher believes that Task-based Language Teaching might help the students as it has already been proven by the other researcher that conduct related studies and already mentioned by some experts about Task-based Language Teaching.

The present study was intended to compare two different learning approaches and they are to be implemented in two different classes to see the significant difference. Both of the classes must be still treated by using Communicative Approach as the mandatory approach in 2006 curriculum. At this stage, one of the classes would be treated by using Communicative Approach with Task-based Language Teaching and the other one class would be treated by using Communicative approach only at this stage. Moreover, as the syllabus of the eighth grade students advises that there are three text genres to be learnt, they are descriptive, recount and narrative, the researcher chose them as the moderator variable.

TBLT is leaded by a theory of learning rather than a theory of language (Richards \& Rodgers, 2001). They also state that the central role of meaning in language use is the one that is being emphasized in TBLT. TBLT allows the language learners to learn something focusing on both, process-oriented and product-oriented. The language learners are also given a chance to discuss their work later after the tasks done. This will be becoming very 
interesting for the students because they can also work with their peers to discuss their tasks at the end of the discussion.

Cao (2012) mentions on her study about Task-based Approach that was applied in EFL writing classroom. The result showed that Task-based Approach was considered to be really feasible for college EFL learners to improve their writing competence. She was emphasizing on shifting the learning activities from teacher-centered writing instructions to students-centered writing instruction. This gave a good impact towards EFL learners' interest to a large extent to participate in a series of communicative activities. Moreover, TBLT also allowed the students to work in peers spontaneously and they are able to interact to others talking about the readers' needs and expectations.

The second study that proved that TBLT is appropriate to be implemented to teach writing comes from Zhaochun (2015). He was concerning on applying TBLT towards English majors in Chinese settings. The focus on TBLT was product -oriented and processoriented. The result of his study showed that TBLT is more effective than the other approaches to improve learners' writing competence. It was not only showing the improvement on writing competence seen from the test scores, but also from the length of the essays and the awareness of collocations and word accuracy. Moreover, it brought to the students' study motivation and interest. The stereotyped of teacher-centered is changed to students-centered approach.

The present experimental research used text types as the moderator variable to control the effect of Communicative Approach with TBLT and Communicative Approach only on the students writing competency. Additionally, Putra, Tantra, and Padmadewi (2016) on their study mentioned the use of text types as the moderator variable to control the treatments given to the students. Therefore, the researcher was confident to use text types as the controller in other to make sure the study was not going too far away from the objective of the study.

In relations to the previous studies about the use of TBLT in teaching writing, the researcher would like to get something new on her research. Therefore, the researcher was eager to conduct something new by applying Communicative Approach with TBLT in this present experimental research. Moreover, the existing use of text types as the moderator variable to control the effect of Communicative Approach with TBLT was also considered as a new thing in the present experimental research.

Based on the above explanation about the students' problem in writing and related theory and studies about TBLT, the writer would like to see the effect of TBLT on the students' writing competency but it would be applied with Communicative Approach. The writer believes that TBLT would definitely help the students in solving their problem related to writing three kinds of texts; they are descriptive, recount and narrative. At this stage, one group would be taught by using Communicative Approach only and the other one would be taught by using Communicative Approach with TBLT.

\section{Methods}

The present study was an experimental study by focusing on two groups comparison post-test only design. The population of the present experimental study was 232 of the eighth grades students of SMP N 2 Kediri in academic year 2016/2017 which in 60 of them were selected as the sample of the study through random sampling lottery technique.

Teaching scenario, posttest, and writing rubric were the instruments of the study. In addition, the posttest was administered after the treatments done in two meetings for each text types. After posttest was done, it was then scored by using scoring rubric. There were seven criteria of the rubric adapted from Davis and MacKay (1996). The criteria are title; 
topic sentence; development; arrangement; diction; grammar; and mechanic. The data were then analyzed by using one-way ANOVA.

\section{Finding and Discussion}

The result showed there was significant difference between the effect of Communicative Approach with TBLT and Communicative Approach on the students' writing competency as shown in Table 1 and 2. In accordance to the result of descriptive analysis, it can be seen that the effect of Communicative Approach with TBLT was more significant than the effect of Communicative Approach. Moreover, based on the analysis of one-way ANOVA, the significant value was a figure of 0.000 which was lower than 0.05 . this indicated that the directional hypothesis which was formulated previously was accepted.

Table 1. The Summary of the Descriptive Analysis of Students' writing Competency

\begin{tabular}{|l|l|c|c|c|}
\hline \multirow{4}{*}{ Group } & \multirow{2}{*}{ Text Types } & \multicolumn{3}{|c|}{ Descriptive Statistic } \\
\cline { 3 - 5 } & & Mean & $\begin{array}{c}\text { Standard } \\
\text { Deviation }\end{array}$ & Variance \\
\hline \multirow{4}{*}{$\begin{array}{l}\text { Communicative } \\
\text { Approach }+ \\
\text { TBLT }\end{array}$} & Descriptive & 82.73 & 5.40 & 29.16 \\
\cline { 2 - 5 } & Recount & 82.46 & 4.63 & 21.44 \\
\cline { 2 - 5 } & Narrative & 82.23 & 4.10 & 16.81 \\
\cline { 2 - 5 } & Grand Mean & 82.47 & & 11.36 \\
\hline \multirow{3}{*}{$\begin{array}{l}\text { Communicative } \\
\text { Approach }\end{array}$} & Descriptive & 79.90 & 3.37 & 9.00 \\
\cline { 2 - 5 } & Recount & 77.23 & 3.00 & 31.58 \\
\cline { 2 - 5 } & Narrative & 73.40 & 5.62 & \\
\cline { 2 - 5 } & Grand Mean & 76.84 & & \\
\hline
\end{tabular}

Source: Data analysis on SPSS 22 Program for Windows, April 2017

Table 2. The One-way ANOVA Analysis of Communicative Approach with TBLT and Communicative Approach

\begin{tabular}{|c|c|c|c|c|c|}
\hline & $\begin{array}{l}\text { Sum of } \\
\text { Squares }\end{array}$ & $\mathrm{df}$ & $\begin{array}{c}\text { Mean } \\
\text { Square }\end{array}$ & $\mathrm{F}$ & Sig. \\
\hline $\begin{array}{l}\text { Between } \\
\text { Group }\end{array}$ & 466.154 & 1 & 466.154 & \multirow{2}{*}{49.818} & \multirow{2}{*}{0.000} \\
\hline $\begin{array}{l}\text { Within } \\
\text { Group }\end{array}$ & 542.714 & 58 & 9.357 & & \\
\hline Total & 881.695 & 59 & & & \\
\hline
\end{tabular}

Source: Data analysis on SPSS 22 Program for Windows, April 2017

Communicative Approach with TBLT allowed students to learn based on the tasks given by the teacher and discussion at the end of the task section. They would need to complete each task by showing their best in writing text types. Moreover, the approach gave opportunities to the students to analyze the indictors of writing and do the tasks 
individually before discussing it classically. Meanwhile, the students who were thought by using Communicative Approach were only focusing on what students have known about writing the texts. Therefore, it could be said that Communicative Approach with TBLT gave significant effect upon students' writing competency compared with Communicative Approach only.

The result of the data analysis was also based on the theory from Richards \& Rodgers (2001). They stated that TBLT can be defined as the unit of planning and instruction in language learning. Moreover, the implementation of applying the approach was also based on their theory. of As in the present study was also focused on giving tasks to the students, Communicative Approach with TBLT allowed the students to work on the tasks given by teacher. The students would need to complete each task to show their understanding. At this point, the teacher gave pre-tasks section to the students. They were given such a brainstorming to build their concept about what was being taught. The second step was giving the tasks and the instruction what should they do to complete the task. If any issues, students were allowed to ask as many questions as possible until they catch the point. The students mentioned that by using this technique, they were able to more understand the material given. It was because the tasks were clear and the instruction was also clear for them. Moreover, at the end of the tasks, they were able to do classical correction to make sure their writings were correct or not according to writing indicators. This was the last steps of TBLT which was post-tasks section.

Moreover, the result that showed Communicative Approach with TBLT gave more significant difference was supported by the theory of Communicative Approach. According to reasons Jarvis and Atsilarate (2014), the English language teaching has been dominated by communicative approach which has been established firmly by itself on a worldwide basis and it has some good historical. The steps of applying Communicative Approach with TBLT was a combination betewen the steps of Communicative Approach and TBLT. The steps of Communicative Approach were exploration, elaboration and confirmation. It was based on 2006 curriculum. Therefore, in this study, the result showed that group which was treated by using Communicative Approach with TBLT gave better achievement in terms of mean score.

The application of Communicative Approach with TBT was also supported theoretically by an empirical study by Littlewood (2004). He mentions that rather than accept common communicative and tasks types, better to show the continuity between TBLT and Communicative Approach and their development. If we refer to interface outside the classroom, communications would reflect the students' needs and interest. However, if connect it to inside-classroom area, it would provide the language components such as grammar, vocabulary and so on that the students must learn to build the communication with the other. This study was a library study so it could support the present study theoretically. This showed that, the combination of Communicative Approach with TBLT was making sense to be implemented.

To conclude, Communicative Approach with TBLT was categorized to be an effective approach to improve students' writing competency. The experimental study also proved that the effect of Communicative Approach with TBLT was more significant than the effect of Communicative Approach upon students' writing competency especially for the eighth grade students. 


\section{Closing}

Communicative Approch with TBLT provided a lot of benefits for the students to practice their writing competency. They could completely finish the task by considering the criteria of a good task. Moreover, they also gave chance to do much more discussion at the end of the task session. This finding was also supported by Littlewood (2004) that confirmed on his library research that Communicative Approach with TBLT is appropriate to be combined.

The writer wishes her great-sincere and heartfelt gratitude to the Almighty of God, Ida Sang Hyang Widhi Wasa for His everlasting blessing so that this thesis could be accomplished.Greatest gratitude goes to all lecturers of English Education Department of Postgraduate Program Undiksha, the writer's family especially her parents and sisters, and all friends for the everlasting support and motivation during the study process.

\section{References}

1. L. Cao. A feasibility study of task-based teaching of college english writing in chinese EFL context. English language teaching , 5 (10). 80-91. (2012)

2. C. Coffin, M. J. Curry, S. Goodman, T. M. Lillis, \& J. Swann. Teaching academic writing: a toolkit for higher education. New York: Routledge. (2005).

3. L. Davis \& S. McKay. Structures and strategies: An intrduction to academic writing. South Melbourne: Acmillan Education Australia PTY LTD. (1996).

4. K. Hyland. Second language writing. New York: Cambridge University Press. (2003).

5. H. Jarvis \& S. Atsilarate. Shifting paradigms: from a communicative to a contextbased approach. Asian EFL Journals , 1 (1). 1-23. (2014).

6. W. Littlewood. The task-based approach: some questions and suggestions. ELT Journal , 5 (4). 319-326. (2014).

7. H. Marashi \& L. Dadari. The impact of using task-based writing on EFL learners' writing performance and creativity. Theory and Practice in Language Studies , 2 (1). (2013).

8. P. M. Putra, D. K. Tantra \& N. N. Padmadewi. The effect of simulated communicative approach on students' writing competency of the seventh grade student of smp widhya bhuana munggu based on text type. Jurnal Penelitian Pasca Sarjana Undiksha, 5 (1). (2016).

9. J. C. Richards \& T. S. Rodgers. Approaches and methods in second language teaching. Cambridge: Cambridge University Press. (2001).

10. F. Tilfarlioglu \& S. Basaran. Enhancing reading comprehension through Task-Based writing activities: an experimental study. The Rreading Matrix , 7 (3). 7-15. (2013).

11. S. Zhaochun. A tentative study on the task-based teaching of writing to english majors in chinese settings. English Language Teaching , 8 (3). 71-79. (2015). 